\title{
The Dynamics of Ethnic Identity Politics in Kenya's Political Landscape
}

\author{
Dr. Anthony Ichuloi* Ph.D \\ Lecturer, Kisii University, Kenya \\ *Corresponding Author: Dr. Anthony Ichuloi, Lecturer, Kisii University, Kenya
}

\begin{abstract}
There is an increasing convergence on the politics of negative ethnic identity in Kenya, thereby eroding the nationalistic identity of the people. My claim in this article is that Kenya is not a democratic country, but a segmented autocratic and ethnocratic nation. Kenyan politics is not about issues, ideas, or ideologies, rather are politics characterized by a negative ethnic monopoly label which generates a clash of ethnic power struggle. Politicians have strategically segmented the country in the line of ethnic tribes and tribal interests at the expense of a unified and holistic nation. Issues of national interest seem not to matter or have not been shown to matter to most senior people in the political class. The nostalgia of self-rule of preindependence is working against the self; the enemy is no longer the white colonialists, but the self-ruled; Kenya's own political class and political systems fight against her own people. However, ethnic identity politics should not be conceived of as per se negative, rather a force that can be used for a more inclusive and cohesive society. This article employs the functional theory of social analysis. This theory explains society as a body with different parts each contributing in a unique way towards its development. It underlines the relationship between the individual and society, the structure of social institutions, the role and possibility of social transformation, as well as issues such as ethnicity, social classes, etc.
\end{abstract}

Keywords: Ethnicity, ethnic identity politics, market identity label, elite class politics, politicisation of economy, intellectual input, development, ideology, civil society politics.

\section{INTRODUCTION}

Politics play a major role in reconstituting the lives of many people in society, whether for the good or bad. Good politics implies good life and bad politics implies bad life. In Africa, the latter seems to explain the fate of many peoples, where political instability seems to explain the reality of African States and their peoples than any other continent in the world. A major cause of African unsteadiness of which Kenya is part can be associated with negative ethnic identity politics under the erroneous colonial principle of divide and rule to the advantage of those behind such political arrangement. ${ }^{1}$ This, in itself, is an issue of critical concern for a politically segmented Kenyan population, scholars and all observers who aspire to see democratic policies and practices in function for a cohesive society. The Kenyan people experience an increasing convergence on the politics of negative ethnicity in almost all facets of their lives including institutions of governance such that informed democracy is looked at as an illusion to many. The deep-seated effect of this is that Kenya has been turned into more of a segmented ethnocracy and autocratic nation, whereby politicians from particular ethnic groups deliberately segment the nation in the line of ethnic tribes and tribal interests at the expense of a unified and holistic nation. In its excruciating and vicious sense, such politics of segmentation are characterized by profound vices like ethnic conflicts, political instability, riots, violence and marginalization of the minority tribes perceived to lack any political influence. These serious vices of national disgrace which should be fought candidly seem not to matter or have not been shown to matter to most senior people in the political class. The political class seem to undermine or are estranged to the ethical theory of leadership advocated by grand thinkers like Plato, Aristotle and Aquinas, and to the theory of justice advocated by John Rawls and many other modern thinkers. The disregard of these theories in the political understanding is fundamentally because they seem not to favour the political class's autocratic agenda, which is to manipulate the beauty and value of ethnicity for their own individual perceived power interests.

\footnotetext{
${ }^{1}$ Posner, Daniel, Institutions and Ethnic Politics in Africa, Cambridge: Cambridge University Press, 2005.
} 
Politics of ethnic division, suppression and manipulation have no place in the postmodern progressive society. For any attempt to build a solid Kenyan society out of its multitude of ethnic groups, it is imperative to allow the power of positive ethnic pluralism to operate. Leaders are challenged to embrace a postmodern philosophy that recognizes the power of pluralism for social integration since it does not aim at suppressing any ethnic group with all its defining characteristics. It is a selfdefeating effort for the political class (as manifested through empty rhetoric of political leaders) in a young democracy, which is supposed to be directed by politics of ideas and progress to regress to the multi-ethnic closed society, while aborting to recognize the beauty behind ethnic differences. In essence, the idea of the postmodern Kenyan society is not to undermine the beauty and reality of each ethnic group for political or social reasons, rather to constitute a more cohesive, plural and accommodative society that recognizes social diversities. In its profound sense, ethnic identity politics when properly channelled should be a force that can be used for a more inclusive and cohesive society. Despite arguments behind the segmentation of negative ethnic identity politics in Kenya, it is also the intention of this article to suggest political solutions that can orient her politics for common social ends.

\section{THE CONCEPT OF ETHNiCITY}

The concept of ethnicity in the postmodern society is very important for an all-inclusive understanding of the dynamics and functions of Kenya's socio-political structures. It is only in recognising social diversities that we find each ethnic group contributing in an exceptional way towards a national plan of action for integral development of the nation. The social construct of ethnicity in any society impacts the daily consciousness of her people since it provides a lens to filter both individual and group social experiences in their process of relating with others in the larger community. In other words, ethnicity in all facets is about identity-status, relevant for both the individual and group self-definition. Kenya being blessed with the human capital of its diverse ethnic groups can truly embrace postmodern ideal of society only if she embraces the philosophy of a positive ethnic pluralism and other diversities for an inclusive and cohesive society. The positive ascriptions to ethnicity for inclusivity are emphasized by Max Weber, particularly when he argues that "ethnic groups entertain a subjective belief in their common descent because of similarities of physical type or of customs or both, or because of memories of colonization or migration; this belief must be important for the propagation of group formation."

It is important to note that the ascriptions pointed by Weber such as: a) a common descent, b) a common history and, c) conceptual autonomy, which are important in themselves for ethnic identity, which should not be misconstrued to imply any form of exclusion of other social groups that constitute the wider collective society. These ascriptions, which are found in diverse ethnic group for their unique identities, from a postmodern perspective, should be a vital force for any pluralistic and tolerant society. Unfortunately, the most critical unease, particularly in Kenya's political landscape is the attempt to politicise such important ascriptions. They are ascriptions manifest diverse ethnic groups' contribution to the national plan of functioning units. In most cases they have been catalysed by political leaders and used as calculative tools for divisive ethnic politics, meant to serve individual interests of some kind. This in essence undermines the philosophy of the postmodern structural society that advocates for social plurality for its proper functioning as undivided unit. Further, it raises fundamental questions: Do the rules for inclusion in any political party and political influence or power require individuals to belong to a particular influential ethnic group? Where do we situate the concerted efforts for inclusive national identity of political parties? The concerns of these intriguing questions are addressed in the subsequent sections.

\subsection{The Ethnic Market Identity Label}

In the introduction above, a contentious claim was made that Kenya is a segmented ethnocratic and autocratic nation. This claim is built on the fact that politicians tend to divide the nation along the line of conflicting tribes and tribal interests at the expense of a unified and holistic nation. The justification of this assertion is what I would term as the "preferred" ethnic market identity label model of politics adapted by self-interested politicians. Many ethnic political leaders within the wider society tactically employ this model of politics when they rush to ethnic groups as shopping centres where supporters

\footnotetext{
${ }^{2}$ Hutchinson John and Smith Anthony, Ethnicity, Oxford: Oxford University Press, 1996, 35.
} 
for their parties are perceived to be grouped. In such a political arrangement, self-proclaimed politicians surface within tribes to make political claims that are apparently perceived to represent the interests of the entire dominant ethnic group, those of the minority and non-influential groups that constitute their shopping basket. In the ethnic market identity label the legitimacy of the ethnic group's relationship to political power is given within the frame of the political party that a particular tribe belongs and alleges to give loyalty by perpetuating the party's intended tribal strategy. ${ }^{3}$ It is all about ethnocracy, where the given set of individual tribes functions as a subset of society with strong economic and political influence over the other groups.

Those behind the ethnic market identity political organization are quickly supported and accommodated by the self-interested influential politicians who are convinced of forming giant monolithic political parties that strategically swallow up the minority groups that are instrumentally considered to serve the interests of the grand parties. ${ }^{4}$ This reality of Kenyan politics is experienced in the advent of every general election, whereby politicians spend public resources running across the entire country, particularly to minority groups, mobilising and luring them with unrepresentative claims of advocating for their ethnic recognition and inclusivity at the national level of leadership through access to basic necessities of life. Instead of selling right political ideologies to the people, self-interests are sold under the pretext of development and inclusivity of the minority ethnics groups. Conversely, this raises the critical phenomenological question of a 'thing-in-itself', different from its 'appearance' in the essence of genuine politics as advocated by grand thinkers like Plato, Aristotle, Aquinas, etc., which is basically selfless service to society.

Kenyan society from independence tends to regard cosmetical appearances (which effect sensations) presented by the political class as real, while undermining enucleating issues of social concern for a real political, inclusive and democratic society. The unreliable promises and goodies given during public gatherings are in a profound sense used as a bait to mismanage the democratic space and process; particularly of the perceived social groups to choose leaders that can bring authentic change to their political disillusionment. It all eclipses the political space for genuine democratic representation necessary and inevitable for progress and inclusivity. This mishap leaves us with a fundamental question: Is this what democracy means in socially divided societies? ${ }^{5}$ Dreadfully, power consolidation through a manipulative instrumentalization of the fragile ethnic relationships makes the overriding objectives of national development a failed project, while few individuals emerge as power brokers and political "godfathers". The flipside of it all is that protecting the vulnerable, which is the reason for any political society, is made apparent; the minority, non-influential ethnic groups are made to think that their interests and political representation are captured by the grand tribal party that ascribes to market their identity. In essence, this raises another fundamental question: Is the voter's party identification the best correlate of right leadership? A certain measure of voter ignorance is, therefore, found a palatable base and rationality to those rallying behind this political strategy.

The politics of ethnic market identity label strategy in the frame of its calculative thinking deploys the knowledge of apparent sensations of development experienced in mini-projects sometimes brought by a particular ruling ethnic class and party, with the postulation of democratic leadership presented to the public that does not reflect the society's correct picture. Under the pretext of giant ethnic political parties, all socio-political attempts are made to mask the rich input of diversity for a richer and inclusive society. The mechanism to this effect is to buy, influence and create an apparent picture of their political parties. The backside of all this is that the apparent image of a political society, which the average Kenyan is given to consume does not perceptibly translate to the change of his/her real life condition. The ambition of the political class is all about hijacking democratic spaces and processes through the strategy of ethnocracy, which consequently leads to divisive tribal politics. Under such political calculations, the meaning of democracy is altered and narrowed down to describe unacceptable political philosophy that is built upon negative ethnicity, influence of particular ethnic groups and the protection of political power with pretentions of proper governance. In its profound sense, the "collective imagination" of a cohesive society is concealed since such social project

\footnotetext{
${ }^{3}$ Chandra, Kanchan, "Ethnic Parties and Democratic Stability," in Perspectives on Politics, June 2005, Vol 3(2): 235-252.

${ }^{4}$ Tercisio Agostino, Every Citizen's Handbook: Building a Peaceful Society, Nairobi: Paulines Publications Africa, 2005, 350ff.

${ }^{5}$ Reilly, Benjamin, Democracy in Divided Societies, Cambridge: Cambridge University Press, 2001.
}

International Journal of Humanities Social Sciences and Education (IJHSSE)

Page | 18 
demands the rethinking of the relationship between ethnicity and politics for better future political ideals through which the national community will seek to determine its identity.

Ethnic market identity label model of politics in essence describes the driving force and a hideout of most of Kenya's political class strategy. This unfortunately creates a desperate and multifaceted search for the establishment and continuance of a well-rounded, vibrant system of democratic governance where people's diverse ethnic experiences for a fulfilling sense of identity that is unshakably rooted in the social, economic and political policies and activities of the nation have become an illusion. The public life of the people is being dominated by the politicisation of their ethnicity and diversity. The existence of ethnically motivated political parties devoid of nationalistic outlook often results in very capable people being excluded from the political space where their positive influence and contribution can be of great benefit for a progressive society. ${ }^{6}$ Furthermore, with the marketing of ethnic identities for political reasons, the minorities and the big population of young people that do not subscribe to this model are not regarded seen as a considerable resource for a diversified and united society.

In the absence of the spirit of genuine national patriotism, manifested by the ethnic market identity political strategy, the country will continue to observe sequences of baffling ethnic contradictions in the form of political disagreement and unsteadiness, irreconcilable fights for power as reflected in the many antagonisms and warfare, the politics of marginalisation, exclusion and domination, accompanied by an incredible variety of micro-ethnic nationalisms and pseudo nationalisms. Faced with such evils, ethnic diversity which is supposed to be regarded as an indispensable element for any healthy and progressive society is undermined. However, it is important to reiterate and emphasize that positive ethnic diversity in all of its forms (cultural, political, sexual, racial, and social) is a potential hallmark of Kenya's progressive future. Politicians are challenged to take into account that Kenya would socially, economically and politically progress if it builds an inter-ethnic corporate society under concerted efforts to build a larger and inclusive nation.

\subsection{The Elite Class Conflict Politics}

Elite class conflict politics is Marxist in nature in the sense that it is the power interest of the political class that matters and nothing else is to be taken into account. ${ }^{7}$ The Marxist class conflict theory of society employed by the elite class, views society as composed of distinct groups with opposing interests, such that any social and political change is a result of struggle among those groups. Society is fundamentally characterized by conflicts leading to division rather than consensus for common interests. In the context of Kenya, throughout its post-colonial history, those in the positions of power employ the class conflict theory of leadership to the height that it impedes it to fully function as a sovereign nation. Under such substantively negative socio-political and economic theory, ethnicity is used as the central organizing principle of the state-rush politics with its successive dynamics of ethnic conflicting differences and exclusion as means to amass and remain in power. The ingredients of such ethnic based politics are motivated emotions that consequently lead to fear, hatred or resentment among competing social groups. ${ }^{8}$ Calculatively, inciting political rhetoric, stirring up their ethnic emotions and reactions against other ethnic groups that are perceived to oppose the mainstream ruling autocratic ethnic group is being sold to the populace. Ethnicity is used as a palliative agent of division and party affiliations are a productive ground for manipulative politics.

The philosophy of divisions and affiliations is to create a self-imposed imaginary enemy to keep the fight going, while demanding strong adherence to calculative rules of a particular party with a radical exclusivity of those who do not confess public adherence to that particular political party. This claim is emphasised by Wilkinson who asserts that those ethnic groups in the lower level of political organization and influence, motivated by resentment erroneously select as their target those ethnic others who are perceived to be farthest up the political status hierarchy whether or not they are the greatest threat to their security. ${ }^{9}$ Some ethnic groups motivated by hatred find themselves targeting those ethnic others with whom they have battled in the past, regardless of their threat potential and

\footnotetext{
${ }^{6}$ Tercisio Agostino, Every Citizen's Handbook: Building a Peaceful Society, Op. Cit.

${ }^{7}$ Nathan Rotenstreich, Alienation: The Concept and its Reception, New York: E. J. Brill, 1989, 78ff.

${ }^{8}$ Petersen, Roger, Understanding Ethnic Violence, Cambridge: Cambridge University Press, 2002.

9 Wilkinson, Steven, Votes and Violence: Electoral Competition and Ethnic Riots in India, Cambridge University Press, 2004.
} 
their position on the status hierarchy. This negative and divisive political arrangement is not new in the entire continent of Africa; it is inherited from colonialism where dysfunctional impediments to political interests are deeply fuelled by the use of political intrigues to disempower any upcoming rivalling ethnic group. In a smart way, colonial powers in Africa empowered certain groups over others and turned primarily social divisions into political ones in order to divide and rule. These divisions inherited from colonialism, wretchedly, to post-colonial leaders are regarded to be functional since they are a breeding ground for their adversely hidden ends. This model of political power-seeking remains the most compelling in African States, particularly in Kenya where the populace is not given the space to make micro-political choices; instead, they are compelled to choose between competing elites offering distinctive political packages of their own devising. In this way the populaces are compelled to choose the narrow path of ethic politics, thereby undermining the broader spectrum of political development and implementation of correct policies for election of genuinely democratic officials. ${ }^{10}$ Under such rationality, a small number of citizens because of their economic power or social status end up dictating almost all political outcomes within society. The preferences of the masses are thereby literally rendered irrelevant, thus compromising any claim of political democracy in the sense of being systematically responsive to the preferences of the people as a whole.

While 'elitism politics' may seem noble and possibly politically provocative, as a political strategy, it is pedestrian and, therefore, not fit in a postmodern society where a sound political rationality is expected to be its guide. Arguments for representative democracy, and for representatives regarding themselves as trustees rather than as mere delegates, ultimately tend to be void in such political approach. The principal factor of elite class politics is weak legitimacy and patron-client or what is commonly known as "godfather" politics alluded to in the preceding section. The intrigue of this assertion is well captured by Fearon, Caselli, and Coleman who argue that there is an association between patronage politics and ethnic politics in societies that employ the class conflict theory of leadership. ${ }^{11}$ When it is enshrined in people's mentality, patronage politics favours coalitions based on ethnic identities and lust for power for economic ends. More emphatically, Janet Landa, following the footsteps of Thomas Hobbes and John Locke, argues that under conditions of political uncertainty, the visibility of ethnic struggle for dominance allows prominent politicians to select influential partners and enforce agreements with them. ${ }^{12}$ For such tribal politicians, partisan politics is perceived to be a profitable game mounted around the machinery of patronage politics, hate speech and incitement of ethnic groups into violence in a manner of creating political misconstruction for substantive corrupt political systems. This assertion is explicated in Kenya's political organization where in the advent of every election there is always a constrained environment for genuine collective participation in the electoral process; it all surfaces the visibility of pronounced ethnic identities and conflicts among groups making their way into voter and party conduct, while undermining a legitimate democratic process. ${ }^{13}$

In class conflict politics, particularly in Africa, disgracefully ethnicity is made into a mechanism by which power is exercised politically in such a way as to pervert the genuine democratic political processes. This is echoed by Rose, who argues that political and ethnic conflicts are deliberate attempts to govern without consensus. ${ }^{14}$ Its underlining rationality is basically to the scheme of extracting or misappropriating public resources for themselves, cronies and respective tribes. In every bid to stem the rising tide of opposition, political leaders, exploit and manipulate the ingrained ethnic divide for political purposes. Because of its palliative nature, this extractive political dynamic generate more pressures as exhibited by the escalating rise of fierceness in political competition for a share of state power. As the political interests take over, it becomes even more practical to attract and reward one's ethnic followers for their loyalty and support to individual political class or party, while excluding others. Basically, there is a perpetual and restless desire for power after power. ${ }^{15}$

\footnotetext{
${ }^{10}$ Przeworski, A., 'Minimalist conception of Democracy: A Defense', in Democracy's Value, ed. I. Shapiro and C. Hacker-Cordón, Cambridge: Cambridge University Press, 1999, 23-55.

${ }^{11}$ Fearon James, "Ethnic Structure and Cultural Diversity by Country", in the Journal of Economic Growth 8.2 (2003) 195-222; Caselli, Francesco and Wilbur John Coleman, On the Theory of Ethnic Conflict, Manuscript, Harvard University Press, 2001.

${ }^{12}$ Landa, Janet Tai, Trust, Ethnicity, and Identity, Ann Arbor: University of Michigan Press, 1994.

${ }^{13}$ Chandra, Kanchan, Why Ethnic Parties Succeed, Cambridge: Cambridge University Press, 2004.

${ }^{14}$ Rose, R., Governing Without Consensus, London: Faber and Faber, 1971.

${ }^{15}$ Hobbes Thomas, Leviathan in John Somerville (ed) Social and Political Philosophy, New York: Doubleday, 1963.
} 
Camouflaging their interests in ethnic or nationalistic terms (such as "advancing the interest of our own people" or "protecting ourselves from another ethnic group") strengthens their pursuits and gives them more political authority over their supporters. In effect, this accompanied by ethnic prejudices and stereotypes against other groups, which are then perceived as a productive ground for the elite political class.

The indubitable and most regrettable fact is that popular participation is enshrined under the fictitious umbrella of ethnicity, while profoundly intensifying exploitation of the hostile ethnic nature of those groups in their struggle to enforce their legitimacy. Deplorably this enforced legitimacy cannot, especially in an ethnically-differentiated society, stimulate national development. Rather, the country continuously moves in a vicious circle of instability that in a determinative way threatens its meaningful existence. Under such a political contrivance, deficient attention is given to pressing problems of national nature like the alarming problem of marginalisation, political instability and national patriotism, ${ }^{16}$ ethnic riots, ethnic violence, ethnic conflicts, historical injustices (land, leadership), and so on. These intrinsic and sensitive issues seem not to matter or have not been shown to matter to the political class. Probably this could be because such issues favour their political agenda, which is to segment and instrumentalise tribes for their own individual perceived interests. These social issues are not in effect about the good of ethnic identities at all, but a reliving of a Hobbesian society of the state of nature that is characterized by a massive disorder due to lack of any focused and unifying authority to enforce order.

"The state of nature is simply the condition where we are forced into contact with each other in the absence of a superior authority that can lay down and enforce rules to govern our behaviour toward each other." 17

Life in this state of nature, reflected in Kenya's political landscape is characterised by solitude, poverty, maliciousness, brutality, incessant tribal wars of all against all. Locke as the contemporary of Hobbes terms this situation the state of war. ${ }^{18}$ In the state of war there is enmity and destruction of people's property and lives such that the important issue of human rights is undermined. It is a situation where an individual threatens the life of another such that the individual whose life is threatened is presumed to have a "right" to annihilate that which threatens him with destruction. This is what Kenyans experienced during the post-election violence of 2007 , where they were forced to live in fear of his/her neighbour. The same repeated itself in the general elections of 2018 where the populace continue to witness the negative fate of their vote. In the political ground, this reality is exhibited through the formation of protective, tribal and regional alliances in the constant and restless desire for power in order to ward off potential opposition who are equally interested in exploiting any opportunity with the end of amassing whatever power that is under their disposal.

The critical issue is that, once the cycle of resentment conflicts begins to be waged in the ethnic group's name, fear and further animosity pervade the entire society, since all members are perceived as the enemy by those against whom the conflict resentment is being waged. The Kenyan populace experienced the aftermath of these political misgivings that generate serious resentful wars and violent conflicts reached their fever pitch in the post-election violence of 2007 instigated by lust for power between President Mwai Kibaki and his rival Raila Odinga, which led to the death of over 1300 people. The paradox of this is that violence engrained in the minds of many vulnerable and frustrated populace seem to be regarded by the political class as a successful exit for political victory. Thus, a conflict started by the elite political class ends up, in a self-fulfilling prediction of a perceived powerful politician, negatively affecting the entire ethnic and regional and national groups. In its profound sense, this is adversely accompanied by ethnic prejudices, which further fuel the conflict making it easy to create an immediate "us" and "them" barrier as well as to demonise the adversary ethnic group. Under such political coinages, social conflicts are primarily of political nature; they are a result of a clash of incompatible interests between political parties founded on ethnic affiliations. Any threat to the goals of such political parties results into ethnic violence geared towards creating fear, hatred and resentment. ${ }^{19}$

\footnotetext{
${ }^{16}$ Bratton Michael and Hydén Göran, Governance and Politics in Africa, Lynne: Rienner Publishers, 1992.

${ }^{17}$ Hobbes Thomas, Leviathan, in John Somerville (ed) Social and Political Philosophy, New York: Doubleday, 1963.

${ }^{18}$ Lock John, The Second Treatise of Government, Oxford: Basil Blackwell, 1966, 4.

${ }^{19}$ Petersen Roger, Understanding Ethnic Violence, Cambridge: Cambridge University Press, 2002.
} 
In essence, the elite class politics create two erroneous publics: elite political class lacking any political ethics and a primordial public defined in terms of its emotive ethnic group identity. ${ }^{20}$ In this, it is the prevalence of a political interest enshrined within ethnic identity reality delineated in terms of where each influential individual politician locates his power. ${ }^{21}$ However, all this undermines the concept of nationhood, where the public is devoid of genuine political rights and duties. The prioritisation of elite power, whether economic or political under the pretext of negative ethnicity is a total hijacking of a positive popular participation and nation-building concerted efforts. If not checked with a critical look of contestation, this erroneous application of ethnic identity politics will bedevil the society to the height of undermining all democratic processes for development. The political resolve to negative ethnic politics is an explicit indication of a lack of genuine national patriotic spirit and of a failed society.

\subsection{Politicisation and Ethnicisation of the Economy}

Politicisation and ethnicisation of the economy is another critical point of Kenya's failed political structure. This finds its flawed justification from Karl Marx's philosophy of economic materialism, where everything, including politics revolves around economy. In other words, social and political facts in Kenya are fundamentally caused by economic facts. The social facts in turn cause consciousness and culture of social members, particularly the political class under the erroneous philosophy that political leadership is thought to exist to enrich those who govern. Today, in Kenya, it is not uncommon to spot prominent professionals (engineers, medical doctors and teachers) abandoning their profession and choose politics simply because their professions are not well paying. This implies that economic facts strongly penetrate and influence political ones, thereby essentially affecting social facts. This whole approach is erroneous since social facts are supposed to give rise to both economic and political facts. It is an upshot which points out to the fact that politics in society cannot be genuinely democratic since they have been made into means to economic gains and not service to society. Politics have been taken as an easy way of access to economic power to the height that politicians persistently seek re-election because holding political office gives them access to public funds, as well as immunity from prosecution in the case when such funds are accessed inappropriately. The incontestable fact of this claim is that political leaders have hidden self-interested economic reasons to advance in their bid for power. Economic interests tend to hide behind their ethnically instigated politics. Instead of making the economy more democratic, the voters are forced to accept 'one dollar one vote' replacing 'one person one vote' because they are bought to sell their vote. This indicting claim finds its explanation from Rousseau, who indicates that the rich seek to enter into a social and political contract with the poor to help them (the rich) safeguard their property. This contract is entirely in the interests of the rich and never for the poor in society. This is central in economic materialistic society with moral-value decadence in both interested parties (the rich and the poor). Subsequent promulgated laws serve the needs of those in power and is expected to work for those who are ruled. From the Marxist point of view, this will be experienced as an alien domination and source of violent passion for wealth. ${ }^{22}$ The entrenchment of economic power into the political arena is endemic to society; it will cost society much of its human and economic resources to the height of disintegrating its social base.

To ground the above assertions for politicisation and ethnicisation of economy, it is justifiable to look at Kenya's economic and political history. The political class amass economic power by mobilizing ethnic groups in their struggle to control public resources. Political leaders hire groups of young, goose, armed men to protect their politicised economic interests that come with their election and reelection into power. It on the basis of this claim that we find almost every election poll since the introduction of multiparty elections in 1992, 1997, 2002, 2007, 2013, 2017 characterised by outbreaks of violence in almost all political rallies organized by the political class and in other social interactions. Much of ethnic violence experienced tends to have a political and economic undertone.

\footnotetext{
${ }^{20}$ Ekeh Peter, "Citizenship and Political Conflict: A Sociological Interpretation of the Nigerian Crisis", in J. Okpaku ed., Nigeria, Dilemma of a Nationhood: An African Analysis of the Biafran crisis, Okpaku Communications, 1978.

21 Ibid.

${ }^{22}$ Rousseau Jean Jacques, "Discourse on the Origin and the Foundations of Inequality among Men" in The Discourses and other early political writings, trans. Victor Gourevitch, Cambridge: Cambridge University Press, 1997, 151-161.
}

International Journal of Humanities Social Sciences and Education (IJHSSE)

Page | 22 
This seems to explain economic inequalities between ethnic groups, which consequently give rise to long-standing bitter disputes and desire to belong to the ruling class. For instance, in the Rift Valley the colonial British administration displaced Kikuyu, Kalenjin, Maasai and other groups from the areas of best land. Optimistically Kenyans drove the British out, however, dreadfully Jomo Kenyatta, Kenya's first post-colonial president, procured formerly Kikuyu land for his fellow Kikuyu elite. The situation worsened when he manoeuvred formerly Kalenjin and Maasai land in the fertile Rift Valley into the hands of poorer Kikuyu under the programme of settlement schemes, thereby setting an environment for ongoing animosity and conflict among those groups while keeping massive tracts of land all over the country for himself and for his wealthy allies. ${ }^{23}$ This betrays the genuine fight for the country's independence for self-rule, turning it into enrichment for one-self and for one's ethnic group, while excluding others.

This same rationality of politicisation and ethnicization of the economy is reprehensibly pictured in the appointment of members to public office, which is fundamentally on the basis of the tribe of those in government. It is the prototype of the representative of the "godfather" and paternalistic model of leadership that is constructed under the undermining principle that ethnic economic power depends upon the tribe of the person(s) in leadership position(s). This indicting claim is supported by the report of the Public Service Commission of 2016 which showed that 297 of the 654 employees $(45.4 \%)$ of State House belong to one ethnic group. ${ }^{24}$ Regrettably, since independence, the State House workforce reflects only two ethnic tribes' presence. The Presidency Cabinet Office, which is the highest office in the land, has 210 staff, but the flip-side of it is that it is dominated by one ethnic group who takes up 35\% of the staff. While the office of the Deputy President, has three tribes taking up $51 \%$ of 310 jobs..$^{25}$ If one's ethnic group is not in any political office, then there are no possibilities of economic or political development of that particular ethnic group. The most disgraceful fact is that all this arrangement is done in total disregard of balance of skills, experiences, ethnic formations, etc., which if taken into account can give a genuine picture of the society for development and co-existence among members.

This deplorable Kenyan political arrangement unfortunately is similar to what happened in Rwanda that led to genocide in the ' 90 s. In the implied country, the Belgian government institutionalized the distinction between Hutu and Tutsi to help keep them from uniting against colonial rule, conferring education and civil service jobs on minority Tutsi and issuing identity cards that formally distinguished between the two groups. When hardline Hutu leaders found their power threatened by both Tutsi and moderate Hutu, they resentfully turned to an organized and coordinated "ethnic war" to split the opposition and maintain power. ${ }^{26}$ The indisputable fact in Kenya is that one ethnic community has accumulated a disproportionate percentage of economic benefits of Kenya's economic growth denying others the possibilities to have equal access to state property. According to the 2007/2008 UN Human Development Index, Kenya ranks 148 of 177 countries on income inequality. ${ }^{27}$ This is justified by the arrangement of personnel in the institutions like Nairobi Stock exchange, the Central Bank of Kenya, and Kenya Electric Generating Company, where all employees come from one ethnic group. ${ }^{28}$

The intriguing issue is that Kenya's economically motivated political structure, inherited from the British, encourages corruption, patronage and inequality. Emphasizing the graveness of corruption on growing economies, the New York Times magazine a few years ago made assertion that the United States alone gives Kenya over $\$ 600$ million a year in aid for development. ${ }^{29}$ We have doctors, lecturers, teachers and nurses going on strike and; for the majority of the public servants to get salary increments they must have recourse to strikes. The exorbitant taxes Kenyans pay and the grants the government gets from donors is not felt anywhere in Kenya's economy. Kenya ranks among the most corrupt governments in the world today, which becomes the only explanation to another claim that the elite groomed political class has disproportionately collected the spoils from the former regimes. For

\footnotetext{
${ }^{23}$ London Guardian, 7/2/2008.

${ }^{24} \mathrm{http}: / /$ www.businessdailyafrica.com accessed on Thursday 16, February 2018.

${ }^{25}$ Ibid

${ }^{26}$ Organization of African Unity Report, 7/7/2000.

${ }^{27} \mathrm{http} / / /$ hdrstats.undp.org/indicators/147 accessed on Monday 20, June 2018.

${ }^{28} \mathrm{http}: / / \mathrm{www}$. bloomberg.com/apps/news accessed on Sunday 26, June 2018.

${ }^{29}$ New York Times, 24/1/2008.
} 
instance, Uhuru Muigai Kenyatta came to power in 2013 promising reforms, but little changed except multibillion corruption scandals: the Eurobond sager, the National Youth Service scandal, the 5 billion lost in the health ministry, etc. With all these monies transacted, the lives of Kenyan people remain the same, languishing in abject poverty. This raised the fundamental question: where does the money go? The irony of it all is that voters tend to elect and re-elect governments who have not managed their economy well; instead, they vote their own pocketbook interests, on the assumption that to be in government as an ethnic implies being their individual economic development. ${ }^{30}$ Under such, Bowles argues that there is no reason to suppose that in the poll booth people would act on the basis of their commitments both to principles of good governance and for politics of service to society. ${ }^{31}$

The fusion of politics and ethnicity with economy is the root cause of governmental corruption, which has contributed directly and greatly to the current breakdown of economic, political and social security in the country. With funds diverted to further enrich the rulers and sometimes particular dominant ethnic groups, the government leaves her people at the mercy of all forms of aggression, including tribal resentment and insecurity. It gives a negative indication that it does not actually protect her population from the incursions that threaten their lives, to the height that she has turned against her own people whom she is supposed to protect. Today, we experience extra-judicial killings committed by the security forces against the population perceived not to be friendly to the ruling class. This is done without any understanding of why they are not feeling part of Kenya's political and economic plan. The erroneous political arrangement by those in power puts into question the Aristotelian apprehension that any government is appraised in terms of the virtue of the ruling body. But the fundamental question is: Do politicians rule for the common good or for their own benefit? $?^{32}$ In order to put things politically according to the rules different from those of the ethnic identity market label arrangement is to essentially separate the two "currencies" - one political, the other economic; ${ }^{33}$ they should not be fused together. Politics are meant to serve society for its integral development and not vice versa.

\subsection{The Oppression of Pre-independence Nostalgia}

Post-independence African States embrace more centralized and authoritarian structure of administration of inherited from their colonizers. In Kenya, particularly as argued in the preceding subsections, this image of leadership strategy is experienced in the splitting up of the country into conflicting regions for political convenience. However, this strategy is a deliberate refutation and betrayal of the people's post-independence dream of a cohesive country. The deceptive embracement of colonial imprint of governance has led optimistic members of society into disenchantment and frustration. Socio-economic growth is basically lacking in many regions of the country, corruption is on the rise in every sector, incompetence at all levels, and government institutions are badly mismanaged. Land grabs are frequently orchestrated by local politicians who mobilise people on the basis of tribal affiliation. Mzee Jomo Kenyatta (Kenya's first post-Independence president) acquired lots of land for himself and his friends leaving many people as squatters that are haunted by the feeling of their own innocent dream of self-rule for self-determination. The above deep-seated issues put into question the role of the state as both a political and a moral institution for the development and unity of its members. ${ }^{34}$ Under such unacceptable and misconstrued instrumentalization of the fight for independence, the fundamental question is: What happened to Kenya's post-independence dream?

The unquestionable fact is that there is a disparity between the pre and post-independence idealistic spirit and the present day divisive and self-interested political strategies. This is where the betrayal of the people's post-independence nostalgia lies. The dream of the revolutionary struggle for independence characterised by selflessness, common vision, a deep love for humanity, integrity,

\footnotetext{
${ }^{30}$ Kiewiet, D. R, Micropolitics and Macroeconomics, Chicago, Ill.: University of Chicago Press, 1983.

${ }^{31}$ Bowles, S. and Gintis, H., "Social preferences, Homo Economicus and Zoon Politikon", in Oxford Handbook of Contextual Political Analysis, ed. Robert E. Goodin and C. Tilly, Oxford: Oxford University Press, 2006, 172-86.

${ }^{32}$ Aristotle, The Politics, Middlesex: Penguin Books, 1988.

${ }^{33}$ Lindblom, A., Politics and Markets, New York: Basic Books, 1977.

${ }^{34}$ Barker Ernest, Introduction, to The Politics of Aristotle, London: Oxford University Press, 1946, 1-li.
} 
honesty, determination, commitment, courage, a talent for mobilizing large numbers of people to participate in the fight against injustice, and the ability to cultivate effective new strategies to meet changing situations. All these issues are now lingering in the minds of many Kenyans who are desperately watching their country being looted by their fellow Kenyans who form the political class. The flipside of it all is that these values have all been displaced by the vices of the political class. The collapse of the dream for a better post-independence future has created an atmosphere of repression and fear, transforming people from truth-sayers to self-interested egoists. ${ }^{35}$ The elite political class fail to deliver transparent and selfless leadership to its own people who put it to leadership.

To this height it is imperative to ask ourselves: What must the populace do to get out of this dreadful depression? We should treat negative ethnicity as only a de facto accident of Kenya's political structure, which tends to reduce the people's rights and legal decisions to strategic political instruments used by the political class to manipulate the rest of society under the pretext of building a cohesive society. Kenyans must read the meaning of their lives on the basis of this oppressed positive nostalgia. The escape window for the populace is to keep the light of their dream for a better society alive and to continuously attempt to collectively own it themselves. Any effort to turn it off or make it "a political offer" to the ruling class is tantamount to the betrayal of the ideals and efforts of all the Kenyans of good will who want to be protagonists of their own progress and social destiny.

\section{Alternative Political Approaches}

Above much has been said about negative ethnicity; however, in today's postmodern and globalised society, ethnic diversity is to be conceived of as a good value to be treasured. Diversity gives people the chance to experience different issues outside of what they are normally accustomed to in their own individual ethnic groups. The recognition of ethnic diversity fits in neatly with the formidability of one united nation such that people who see themselves as belonging to oppressed groups get to perceive themselves as indispensable and equal partners in the whole enterprise of building one solid and united nation. As perceived by great minds like Plato and Aristotle, the state is nothing else other than the individual enlarged. In other words, the individual in his or her diversity is to be taken into account for the state's identity and progress. ${ }^{36}$ This is where positive ethnicity and diversity is paramount for State identity. Unfortunately, when ethnic diversity is not given a positive valuation, then it may lead to inability to endorse ideas of unity of intent at the national level; the inability to gain agreement on decisions, and inability to take united actions. Thus, from a postmodernist approach to social organization, politics of identity in diversity (of tribes, gender, weak, minorities, etc.) is inevitable if Kenyans have to find solutions to their political, social and economic progress. This will be explained in the subsequent sections.

\subsection{Ethnicity and Social Harmony}

As it has been discussed in the preceding paragraphs, negative ethnicity is a political coinage and strategy for political interests of those in power. The country's ethnic groups have been divided, prejudiced and stereotyped about each other. These attitudes never turn into conflict at the people-topeople level unless manipulated and organized by political leaders. ${ }^{37}$ In this subsection, the fundamental assertion is that people's ethnic similarity and differences is the basis for participatory democracy and social harmony. For social harmony and cohesiveness, it is imperative that the power be invested on the people themselves since society depends on mutual trust of her members. It is a about the transition from the installation of anarchy and the investment of sovereign power on one individual as claimed by Hobbes to proper ownership of leadership for the good of society in a positive democratic sense. This is a position held by John Locke when he assertively argues that genuine social harmony is impossible when one is subject to the arbitrary will of another influential human being in society. ${ }^{38}$

The insatiable political wills of the political class need to be regulated by authentic social, legal and political structures such as strong judicial systems to enhance laws, ensure penalties and to give effect to the rule of law for order in society. This is where the Social Contract theory of Jean-Jacques

\footnotetext{
${ }^{35}$ Ngugi wa Thiong'o, Penpoints, Gunpoints, and Dreams, Oxford: Oxford University Press, 1998, 15.

${ }^{36}$ Plato, The Republic, Middlesex: Penguin Books, 1987.

${ }^{37}$ Bhardwaj Raman, The Dilemma of the Horn of Africa. New Delhi: Sterling Press. Bhardwaj, 1979: 169.

${ }^{38}$ Lock John, The Second Treatise of Government, Oxford: Basil Blackwell, 1966, 4.
} 
Rousseau ${ }^{39}$ which encourages transparency in liberal democracy with efforts to expand participation in political affairs becomes a constructive insight into Kenya's political landscape. Unfortunately, as explained above, Rousseau's innovative political ideas have been subjugated by the power hungry authoritarian political elites. This group has selectively used Rousseau to justify their exploitative ethnocracy with individual invested interests under the umbrella of ethnic inclusivity political arrangement.

Proponents of bureaucratic states, as the case with many African leaders have also appealed to Rousseau's endorsement of the moral superiority of governing by impersonal rules as exhibited by authoritarian regimes. However, the most fundamental and innovative idea of Rousseau's political consideration is that the "savage man" manifested through Kenya's ethnocratic political class, which undermines the democratic and sovereign will of the people should not be qualified to fit into the postmodern Kenyan society.

Enlightened by Rousseau's political reflection, it is self-evident that Kenya's segmented ethnic groups suffer from lack of national consciousness of their apparent political situation. This lack disables them from any positive contribution they can make for an inclusive and cohesive society. Growing in such consciousness could be a relatively apt way of coming out of political manipulation and social segmentation that has led to autocratic ethnic lines. Through national consciousness, the general and inclusive will of the entire society can be heard and revealed as cohesive force for a proper change and development of members in society. This is basically because the common laws of the general will of the members are in essence for the common good; they are impartial, non-self, all for the good of all members for an inclusive and cohesive society. This is where each member of society as an individual enlarged is important for the building of a bold and active society.

Because sovereignty resides in the whole body of Kenyan people, ${ }^{40}$ and not merely in any particular individual or ethnic group, then it is the total control of the people that will prevent them from being exposed to oppression by any ethnocratically motivated leaders that apparently seem to be greater than the people themselves. The basis of this is to foment consensual rather than majoritarian, with proportional representation in many dimensions of society. Obviously, the contending parties need to be prepared to work together on those terms if the system is to work at all. But as long as those rules are broadly agreed and broadly respected, society can function politically with virtually nothing else being contained in a socially overlapping social consensus. ${ }^{41}$ The self-governing power of the people admits no law or power higher than itself since it is the authority of people themselves that is the source of all law and power.

Ethnic diversity can be a powerful tool for the formation of a solid cohesive and complementary society, with positive politics providing the motivation to function as a unified front. Without doubt, groups or tribes with many values, such as common history, language, membership for easy convention, have been manipulated by the political class with a different narrative to the extent that these values have been turned into vices. However, Kenyans should optimistically capitalise on the structure of their tribal diversity to build a cohesive and inclusive modern society. Political leaders can also use political incentives like ethnic recognition to entice their followers to join and support the national craving for a united nation. Due to their highly respected social standing, these leaders can further use their positions to exert influence on the members of their respective tribes to embrace tolerance and differences. Lacking the ability to accept and learn from one another, individual conservative tribes will continue to zip themselves inward and eventually stagnate. But when the concerns of all can be heard, the opportunity for acceptance of the other for coexistence is experienced.

Authentic transition to democratic process will occur in Kenya when different ethnic groups that have coexisted peacefully for decades, if not centuries are encouraged by government officials to acknowledge their ethnic differences and tolerance for the creation of ethnically accommodative political structures. The country has already a long history of coexistence and cooperation between

\footnotetext{
${ }^{39}$ Rousseau Jean Jacques, "Discourse on the Origin and the Foundations of Inequality Among Men”, in The Discourses and other early political writings, trans. Victor Gourevitch, Cambridge: Cambridge University Press, 1997, 151.

${ }^{40}$ Kenyan Constitution, Chapter One: Sovereignty of the People and Supremacy of the Constitution, 2010.

${ }^{41}$ Lijphart, A., Patterns of Democracy, New Haven, Conn: Yale University Press, 1999.
} 
small ethnic groups, which should be used to speak out against the ethnic segregation that is being imposed on them from the top ruling class. The ideal measure is when tribal politics allow persons of like minds or backgrounds to have a unified, open and inclusive voice that takes into account the voices of other tribes.

As a postmodern society that is not determined by conventional approaches that looked for contestable elements of ethnic societies for their subsistence and relevance, positive ethnic identity is indispensable. ${ }^{42}$ Any misguided attempt to resort to negative tribal and divisive politics is a violation of the richness of diversity and indication of an intellectual vacuum created by lack of informed young generation ideology, which encompasses diversity and democratic processes.

\subsection{Politics of Civil Society}

Close to ethnicity and social harmony is the politics of civil society. A thriving democracy presupposes a thriving civil society, independent of the political establishments and consistent attempts to provide inputs into it. One way of realizing this is creating a social space where social decisions are reached through civil participation in matters affecting the people. This in one way is expressed through the vote, where voters basically vote right leaders to represent them. However, before the vote, they engage in deliberating issues of their concern that they deem fundamental to them that later proposed as a political project to their leaders. They somewhat before voting talk to friends and family; they argue in the social places and participate explicitly and sensationally in public debates through the mass media and other available social platforms. ${ }^{43}$ This gives them the social and democratic space to reason together, in a more deliberative, discursive way. Democratizing social space in essence focuses on the need for more participation and deliberation by the public in everything from shopfloor decisions to organized public participation. ${ }^{44}$ The deliberation of matters of social concern together with others makes one more empathetic and one's preferences more publicspirited and less narrowly self-interested. ${ }^{45}$ Democracy presupposes certain broad bases of agreement within the larger civil society. Whether phrased in radical terms of "hegemony ${ }^{46}$ or more modest ones of 'social prerequisites', ${ }^{47}$ the basic idea is that in order to govern any moderately diverse plural community there must be 'agreement' among the contrasting subgroups, not necessarily on substantive issues, but at least on the basic procedures by which substantive disagreements of whichever kind are to be resolved; agreements are the basic procedures of democracy itself. The political situation described in the preceding subsections presents a vital call and attempts to make democratic decisions 'more deliberative'.

Public participation and deliberation is an open window through which Kenyans are able to break from the "grand tribal narrative", defining their political reality and find within their divisive political history reasons to unite. In their history they are challenged to foment a "collective imagination" of a postmodern State that finds pluralism as a basis for integral development. However, this demands the rethinking of the relationship between their political and social realities, embodied in their history. Any attempt to decline in civic participation across the board, including not only participation in politics (voting, campaigning and so on) but also, crucially, participation in voluntary associations that have historically been the incubators of political and socio-economic change is of great danger to a developing nation like Kenya. ${ }^{49}$ The politics of civil society have worked in many parts of the world; they have helped to breakdown communism in Eastern Europe ${ }^{50}$ they have brought democracy

\footnotetext{
${ }^{42}$ Mayall, James, "The Roots of National and International Conflict in the Horn of Africa," Unpublished paper presented at the Regional Security Conference, Cairo, May 1990, 2.

${ }^{43}$ Yankelovich, D., Coming to Public Judgment, Syracuse, NY: Syracuse University Press, 1991

44 Fung, A. and Wright, E. O., eds: Deepening Democracy: Institutional Innovations in Empowered Participatory Governance, London: Verso, 2003.

${ }^{45}$ Wilson, J. Q.: 'Interests and deliberation in the American republic', PS: Political Science \& Politics, 23 (1990), 558-62.1990.

${ }^{46}$ Laclau, E. and Mouffe, C., Hegemony and Socialist Strategy, London: Verso, 1985.

${ }^{47}$ Przeworski, A., Democracy and the Market, Cambridge: Cambridge University Press, 1991

${ }^{48}$ Goodin, R. and Tilly, C., eds: Oxford Handbook of Contextual Political Analysis, Oxford: Oxford University Press, 2006

${ }^{49}$ Putnam, R. D., Bowling Alone: The Collapse and Revival of American Community, New York: Simon \& Schuster, 2000

${ }^{50}$ Cohen and Arato, 1992.
}

International Journal of Humanities Social Sciences and Education (IJHSSE)

Page $\mid 27$ 
in the USA and other developed democracies, they encourage to build social trust in institutions as well as a 'social capital' for socio-economic development. ${ }^{51}$ In a true democracy, power is invested in the people; people's sovereignty is the basis for a true social change where the rulers elected by the people play their role as a correct reflection of their democracy. Unfortunately, it is because of the indecent perception of those in leadership that the efforts to deepen democratic principles on the basis of the rule of law and people's true participation have received little attention. The political frame of those in power seems to be focused on ethnic motivated politics for power and not for leadership. As it has been alluded above, political leaders rally people, especially of their own tribes to register in order to vote for them, while other minority tribes are only used as top-ups. Dreadfully, these trends conceal the positive influence tribal politics can exert on the democratic process in society.

The test of true politics of civil society in Kenya is not about the prevalence of ethnic diversity per se, but the proper use of diverse ethnic identity politics and participation that take into account and represent the entirety of the interests of the people. It is about the Kenyan people collectively giving their politicians what they ought to do for them as their representatives and not what the politicians think they can do for the people. This is inimical to social and democratic progress. Kenyans have to note that the politics of ethnic affront shelves more concrete, pressing issues, like poverty, police brutality, people's representation, recognition, etc. that affect the entire society. ${ }^{52}$ These are key issues that call for proper and national representation and recognition of those affected by them for a cohesive society. Politics of personal and individual interests tend to eclipse these key issues which should form ideology based politics.

\subsection{Politics of Intellectual Input}

Politics of intellectual input in any postmodern and growing technological society is an indispensable tool for sound political systems. For this to be realised there should be an enlightened, educated and learned political class. Contrary to this will be equal to having political systems that are under leaders who suffer from chronic intellectual preparation decadence. It is a common mishap in Africa to have political leaders who do not even meet the basic intellectual requirements necessary for the office they hold. This intellectual depravity is manifested when parliamentarians and county government representatives physically confront each other in their proceedings and some even boycott public debates that provide political platforms where issues of national interest are discussed and addressed; this justifies the claims that the dynamics of Kenyan politicians is about individuals and not issues. Intellectual depravity impoverishes the debates around matters of national interests that demand profound reflection. It is on this basis that politics of intellectual input becomes essential in growing democracies and governments like Kenya that turns to her people after every five years for approval to lead them.

The fundamental objective of politics of intellectual input is to spearhead educative political discussions, programmes and campaigns that reflect public and civil education for an informed public participation. In essence, it is about the nurturing of a functioning society on the principles of enlightened participatory democracy and people's informed consent in democratic processes. It offers intellectual spaces for debates which educate and inform the public about matters of national interest against individual interests. This is basically because public participation should not be conceived from the conventional strategy restrained in the exercise of mass voter registration and general elections. In politics of intellectual input, conversely, politicians do not provide the political agenda and not even the dynamic of the discussion to the populace; rather it is the informed public which provides their politicians with what they should do for them before, during and after they have been elected in office. In effect, the work of politicians is to tailor the agenda of the electorate that reflects the will of the entire nation. ${ }^{53}$

The political class ought to balance the requirement to create a vibrant central authority with the need to recognize and integrate the country's more robust existing institutions (the tribes, the media houses, interest groups, Judiciary, non-governmental institutions, etc.) into state structures of leadership. This

\footnotetext{
${ }^{51}$ Putnam, 1993; 2000; Skocpol and Fiorina, 1999; Macedo, 2005.

${ }^{52}$ Barker, Ernest, Introduction, to The Politics of Aristotle, London: Oxford University Press, $1946,1$.

53 Rousseau Jean Jacques, "Discourse on the Origin and the Foundations of Inequality Among Men", in The Discourses and other early political writings, trans. Victor Gourevitch, Cambridge: Cambridge University Press, 1997, 150ff.
} 
can be put into effect by the building of modern inclusive political parties with a national trade mark, which should offset tribal politics. The fundamental tool for inclusive politics is the exercise of policy debates. Debates are open horizons where politicians are given an open opportunity to demystify the issues of negative ethnicity perpetuated and experienced by the rest of society for a long time. Since they are not founded under the erroneous slogan that "if you don't think like me, then you are my enemy" employed today by the majority of antagonist and inciting politicians, policy debates are a key element of participatory democracy. They help political leaders and their parties to come up with policy based political agendas enshrined in their political manifestos. The ideas in their manifestos are questioned and leaders held accountable to their promises to the people. Furthermore, under policy based politics, specific manifestos would foster healthy political competitions that would force parties to progressively distinguish themselves from each other for the benefit of the entire society. Equally, such debates would also help to illustrates incontestable areas of common interest.

Public participation, in the scheme of politics of intellectual input, covers online engagement which involve activities such as online voting and public discussion forums that give citizens the opportunity to voice their opinions on topics and offer solutions as well as find others with common interests while creating the possibility of forming advocacy groups pertaining to particular interests. All these elements offer citizens the opportunities to be intellectually involved in their governance that they would not have otherwise, by allowing them to voice themselves from their marginalised zones. The use of the internet technology has globally allowed people to have access to information easily, thereby giving rise to a better informed public as well as creating a new sense of both cyber and conventional community for citizens. Such innovative public participation addresses and responds to the normative measures while educating the public on their positive role in society.

Furthermore, politics of intellectual input offers 'universal insights' to resolve the issues of national interest that affect society; it focuses on social developmental issues as strategies for political process. By identifying social issues, political parties create genuine development platforms that will launch initiatives that reflect popular needs. Such platforms form democratic spaces where people are open to discuss concerns of public interest and putting means to make political changes necessary. This kind of political participation is to be practiced with regularity, involving public meeting sessions for discussions where the popular society is informed and encouraged to take part in leadership transformation and inculcation of democratic principles in their party manifestos.

Party manifestos are fundamentally documents in which parties outline their principles and goals in a manner that goes beyond popular rhetoric manifested in public political rallies that are characterised by talking to the public and not with the public. Party manifestos arise from careful discussion, compromise, and efforts to express the core values and commitments of the party as demanded by the electorate. By stating a vision for the future that reflects the will of the people in their manifestos, then individual politicians will not see themselves as protagonists and solutions to the social problems, but simply executioners of the people's political project. Additionally, political parties are also obliged to provide voters with ways to measure their performance. For that reason, forging platforms where political manifestos are debated and challenged transcends divisive tribal and paternalistic politics that have destroyed people's sound participation for self-governance.

It is, therefore, substantively imperative that accommodating the public's intellectual input for political progress is indispensable for any political administration that looks forward to innovative and transparent ways of serving her people; it allows for concerted efforts and peoples' informed participation in public-affairs discourse of society that correct the traditional, manipulative and divisive narrative of the "godfather" political strategy. There is no doubt that the way forward for inclusive politics in Kenya lies in the people's resolute efforts to build modern political parties founded on development ideas and not mere ethnic autocracy. The subsistence of such a political basis requires that party competition for power be founded on the foundation of development platforms supported by the search for ideas that encourage postmodern and technological political arrangement and not divisive appeals to tribal coalitions that mask the positive power of social and ethnic diversity.

\subsection{Politics of National Ideology and Development}

Frantz Fannon, a renowned African writer in his various works claims that African suffers from lack of national ideology. For him lack of national ideology is the basis for the disintegration of African 
societies, since they lack unity of intent for a common goal. However, it is important to note that politics of intellectual input alluded to in the preceding subsection is the enucleating force for the politics of national ideology. Politics of national ideology sets a basis for sustainable politics of development; it is a force behind government institutions and greatly influences the economic viability and success of government institutions that put into motion democratic processes. The concept of development I have alluded to consists of a) an aspect of change; b) a plan or prediction and, c) involvement of government leadership for the achievement of that planned or predicted goal. Taking these elements into account, politics of development necessarily grows from politics of ideology which is all about the process of allowing and encouraging people to meet their aspirations; it is all about the transformation of the entire society enmeshing together its economic, social, political and administrative aspects. ${ }^{54}$

Furthermore, politics of national development founded on the politics of national ideology is essential in building a system of progressive and cohesive governance that takes a positive account of existing social and ethnic diversities and relationships instead of simply manipulating them by those in authority or those aspiring to be in authority. The lack of political ideology is exhibited when politicians go to historically marginalized tribes with baskets of goodies under the pretentions of development, while their genuine project is to win votes in order to retain power. Such traditional communities are perceived or countered as mere voters, where their votes count but not themselves as persons. Genuine politics of development takes into indubitable account exclusivity and marginalization of other tribes as an essential element of government planning. Undermining this would mean forming a parallel power structure that will undermine the formal institutions of the nation. Certainly, today, we find issues such as education, health, infrastructure, energy, transportation, irrigation, and telecommunication and youth employment are emerging as common themes in political agendas, even though it is still in the level of its commencement. Once such issues are identified and given the weight they encompass in government planning, then political parties will be obliged to embrace and enshrine them in the agenda of every political movement in the country. This later becomes the principle of national interest for national self-determination ${ }^{55}$ as pointed out earlier in Rousseau's concept of people's sovereignty.

The predominance of such national issues of development as the basis for political ideology politics selects pragmatic leadership as implementation of the politics of progress for social change. Obviously, political parties may differ on essential points, but respecting the ideology of a national project, they are obliged to offer realistic approaches for its implementation. Such debates are central pillars for growing democracies; they are genuine platforms for the politics of growth, which should replace manipulative and divisive tribal politics of regression nature employed by the political class.

\section{CONCLUSION}

The enucleating and indicting argument of this article has been that Kenya is a segmented ethnocratic and not a democratic nation. This assertion has been based on the fact that Kenyan politics tend to undermine the politics of issues, ideas, or ideologies that picture a collective imagination; rather it perpetuates politics characterized by negative ethnicity which generates ethnic-social conflicts. It has been explained that negative ethnicity in the political setting is being used as a shield by the political class to conceal their economic interests, while dividing the society into irreconcilable interest groups. Politicians tend to segment the nation in the line of conflicting ethnic tribes and tribal interests at the expense of a unified and holistic nation. It has been discussed that such model of political organization if not critically embraced is a real threat and a stumbling block to people's nationalistic dream for an inclusive and cohesive society. Kenya's ruling class has failed to establish a nation-state characterised by a truly harmonious, peaceful and democratic principles.

The article has also argued that to overcome negative ethnicity oriented politics, equal amount of effort should be put into exploring and articulating a more positive philosophy of ethnic identity politics which is a characteristic of a postmodern society. It is possible to legitimize ethnic identity

\footnotetext{
${ }^{54}$ Basu Asish, Tribal Development Programmes and Administration in India, New Delhi: National Book Organization, 1985.

${ }^{55}$ Markakis, John, Nationalities and the State in Ethiopia - An Interpretation, Series no. 63, The Hague: Institute of Social Studies, 1989, 4-6.
}

International Journal of Humanities Social Sciences and Education (IJHSSE)

Page $\mid 30$ 
politics without making it incompatible with the formation of a larger cohesive unit of society for a national plan of action. Political preoccupation with exclusivity by social necessity should be counterbalanced by politics of development, ideology and of intellectual input. To achieve this, the article has demonstrated that the foundation should be politics of civil engagement, correctly informed elite political class and professionals' participation. Social cohesiveness cannot take hold if the entire Kenyan society is not committed to democratic processes and do not have faith in their democratic principles. Instead of using the tribal model to co-opt civil society, the ruling class should provide a participatory environment for the populace to build their own society under the principles of democracy for cohesive existence.

\section{AUTHORS' BIOGRAPHY}

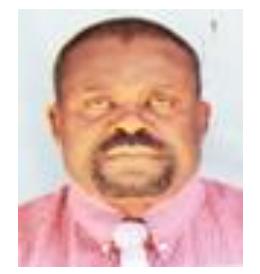

Dr. Anthony Ichuloi owns two Masters Degrees: One in Moral Theology and the other in Philosophy; a $\mathrm{PhD}$ in Philosophy. He has taught in various institutions in Kenya and in South Africa. He is currently a full time lecturer in Kisii University. Chair of Department of Philosophy and Religious Studies

Citation: Dr. Anthony Ichuloi Ph.D. “The Dynamics of Ethnic Identity Politics in Kenya's Political Landscape" International Journal of Humanities Social Sciences and Education (IJHSSE), vol 5, no. 11, 2018, pp. 16-31. doi: http://dx.doi.org/10.20431/2349-0381.0511003.

Copyright: (C) 2018 Authors. This is an open-access article distributed under the terms of the Creative Commons Attribution License, which permits unrestricted use, distribution, and reproduction in any medium, provided the original author and source are credited. 